\title{
Pola Perubahan Protein Koro Benguk (Mucuna pruriens) Selama Fermentasi Tempe Menggunakan Inokulum Raprima
}

\author{
The Pattern of Changes in Protein of Velvet Bean (Mucuna pruriens) during Tempe Fermentation \\ using Raprima Inoculum
}

\author{
Novia Aristi Rahayu, Muhammad Nur Cahyanto, Retno Indrati ${ }^{*}$ \\ Departemen Teknologi Pangan dan Hasil Pertanian, Fakultas Teknologi Pertanian, Universitas Gadjah Mada, \\ Jl. Flora No. 1, Bulaksumur, Yogyakarta 55281, Indonesia \\ *Email: indrati@ugm.ac.id
}

Tanggal submisi: 10 Desember 2018; Tanggal penerimaan: 22 April 2019

\begin{abstract}
ABSTRAK
Tempe merupakan makanan sehat dikarenakan kandungan komponen bioaktif dan merupakan sumber protein bagi vegetarian. Selama proses fermentasi, jamur tempe akan menghasilkan enzim protease yang memecah protein biji menjadi peptida bioaktif. Jenis jamur tempe dan lama fermentasi akan mempengaruhi peptida bioaktif yang terbentuk. Penelitian ini bertujuan untuk mengetahui pengaruh ragi tempe Raprima terhadap perubahan konsentrasi peptida dan pola protein selama fermentasi tempe koro benguk. Hasil penelitian menunjukkan aktivitas proteolitik mengalami kenaikan cepat pada awal fermentasi tempe dan mencapai aktivitas optimumnya pada fermentasi jam ke-96 sebesar 0,046 U/mL. Tempe mengalami perubahan $\mathrm{pH}$ dari awalnya sebesar 7,01 kemudian turun menjadi 5,92 pada fermentasi jam ke-30 dan kemudian naik kembali sampai dengan pH 7,25 pada akhir fermentasi (120 jam). Kadar peptida mengalalami peningkatan seiring dengan bertambahnya waktu fermentasi. Derajat hidrolisis meningkat cepat sampai 24 jam fermentasi kemudian mulai stabil pada jam 96 $(46,31 \%)$. Pengamatan dengan SDS PAGE memperlihatkan terbentuknya protein/peptida dengan berat molekul $<25 \mathrm{kDa}$ hasil hidrolisis protein koro benguk selama fermentasi menggunakan ragi Raprima.
\end{abstract}

Kata kunci: peptida; protease; Raprima; tempe; koro benguk

\begin{abstract}
Tempe is a nutritious healthy food because it contains bioactive compounds that are beneficial to human health. This product is good for those who are vegetarian. During the fermentation process, fungi produce proteases that break down the velvet bean's proteins into protein fragments or peptides which have functional properties. The fungus strain and the duration of incubation time will affect the bioactive peptides formed. This study aimed to determine the effect of tempe inoculum on changes in peptide concentration and protein patterns during fermentation. The results showed that proteolytic activity increased rapidly at the beginning of tempe fermentation and reached its optimum activity in $96 \mathrm{~h}$ fermentation period $(0.046 \mathrm{U} / \mathrm{mL})$. The $\mathrm{pH}$ of tempe changed from 7.01 then decreased to 5.92 in $30 \mathrm{~h}$ incubation, after that it increased again to 7.25 at the end of fermentation time $(120 \mathrm{~h})$. Peptide concentration increased with increasing fermentation time. The degree of hydrolysis increased rapidly until $24 \mathrm{~h}$ of incubation, then began to be stable until $96 \mathrm{~h}$ of incubation (reaching the hydrolysis degree of $46.31 \%$ ). SDS PAGE patterns showed the formation of proteins/peptides with a molecular weight of $<25 \mathrm{kDa}$ as a result of hydrolysis of velvet bean protein during tempe fermentation using Raprima inoculum
\end{abstract}

Keywords: peptide; protease; Raprima; tempe; velvet bean 


\section{PENDAHULUAN}

Indonesia kaya akan kacang-kacangan lokal yang merupakan sumber protein nabati seperti koro-koroan. Koro benguk dikenal dengan sebutan velvet bean dalam bahasa Inggris dan memiliki nama ilmiah Mucuna pruriens (L). Kultivar koro benguk pada umumnya tahan terhadap kekeringan dan dapat ditanam pada lahan tandus. Produktivitas kacang koro benguk sekitar 3-4 ton/ha, lebih tinggi dibandingkan produktivitas kedelai yaitu sekitar 1-2 ton/Ha. Kandungan protein biji koro benguk sekitar 28,4-31,0\% (Handajani, 2001), yang $22,7 \%$ nya adalah globulin dan albumin (Siddhuraju dkk., 1996). Asam amino esensial yang terdapat pada kacang koro benguk adalah valin, isoleusin, tirosin, fenilalanin (Sidduraju dkk., 1996).

Saat ini tempe menjadi makanan sehat yang populer di dunia dikarenakan kandungan komponen bioaktif dan manfaat kesehatannya. Tempe dikenal sebagai salah satu pangan fungsional yang memiliki sifat sebagai antioksidan, antimikroba, antikanker, antihipertensi, antitrombotik dan hipokolesterolemik (Gibbs dkk., 2004). Tempe koro merupakan tempe berbahan baku kacang koro seperti koro pedang putih (Canavalia ensiformis), koro kratok (Phaseolus lunatus L.), kacang gude (Cajanus cajan) dan koro benguk (Mucuna pruriens). Kandungan protein yang cukup tinggi menjadikan tempe koro-koroan berpotensi sebagai bahan pengganti tempe kedelai di Indonesia.

Selama proses fermentasi tempe, Rhizopus $s p$. menghasilkan enzim protease yang akan menguraikan protein menjadi fragmen-fragmen yang mudah larut air. Kemampuan Rhizopus sp. memproduksi enzim protease mempengaruhi pembentukan peptida bioaktif selama fermentasi tempe koro. Aktivitas protease fermentasi tempe kedelai terdeteksi setelah fermentasi 12 jam ketika pertumbuhan jamur masih relatif sedikit (Hidayat dkk., 2006).

Pembentukan peptida bioaktif selama proses fermentasi tempe dipengaruhi oleh jenis jamur tempe dan lama fermentasinya. Peptida bioaktif merupakan fragmen protein spesifik yang mempunyai dampak positif terhadap fungsional dan kondisi tubuh (Kitts dan Weiler, 2003), umumnya memiliki berat molekul rendah, terdiri dari 2-20 asam amino spesifik dan bersifat hidrofobik (Himaya dan Kim, 2012). Peptida bioaktif dapat dihasilkan dari (1) hidrolisis enzimatik, (2) proses pengolahan pangan (panas dan kondisi alkali) dan (3) degradasi proteolitik mikroorganisme.

Tujuan dari penelitian ini adalah mempelajari proteolisis yang terjadi selama fermentasi tempe koro benguk menggunakan inokulum komersial (ragi Raprima) dan pengaruhnya terhadap $\mathrm{pH}$, konsentrasi peptida, derajat hidrolisis dan profil protein.

\section{METODE PENELITIAN}

\section{Bahan Penelitian}

Koro benguk (Mucuna puriens) dan ragi tempe Raprima dibeli dari pasar lokal. Bahan kimia: orthophaldehyde (Sigma-Aldrich), protein marker (Biorad), $\beta$-mercaptoetanol (Merck), dan bahan kimia lainnya merupakan bahan berstandar analisis (p.a).

\section{Pembuatan Tempe Koro}

Metode pembuatan tempe koro benguk mengadopsi dari pengrajin tempe di Daerah Istimewa Yogyakarta dengan menggunakan daun pisang sebagai pengemas dan penambahan ragi Raprima 0,2 \% sebagai inokulumnya (Gambar 1).

\section{Ekstraksi Protease Tempe}

Ekstraksi enzim protease mengacu pada Elegado dan Fujio (1993), 1 gram tempe dihancurkan kemudian ditambahkan $3 \mathrm{ml}$ buffer fosfat $(0,05 \mathrm{M}, \mathrm{pH} 6)$ dan dihomogenisasi menggunakan waring blender selama 2 menit kemudian diinkubasi pada suhu $30{ }^{\circ} \mathrm{C}$ kecepatan 60 rpm selama 30 menit. Sampel kemudian disentrifugasi pada kecepatan $9391 \mathrm{~g}$ suhu $4{ }^{\circ} \mathrm{C}$ selama 10 menit. Supernatan merupakan larutan enzim protease.

\section{Analisa Aktivitas Protease}

Pengukuran aktivitas protease secara kuantitatif dengan metode Sigma Aldrich dengan sedikit modifikasi (semua analisa yang dilakukan dalam penelitian ini dilakukan secara duplo). Sebanyak $5 \mathrm{~mL}$ 0,65\% larutan casein diinkubasi selama 5 menit dalam waterbath 37 ${ }^{\circ} \mathrm{C}$, kemudian ditambahkan $1 \mathrm{~mL}$ larutan enzim protease dan kemudian diinkubasi pada suhu $37^{\circ} \mathrm{C}$ selama 10 menit. Setelah inkubasi tambahkan $5 \mathrm{~mL}$ reagen TCA pada masing-masing tabung untuk menghentikan reaksi. Larutan kemudian disentrifugasi pada kecepatan $6000 \mathrm{rpm}$ selama 10 menit. Tambahkan $5 \mathrm{~mL}$ sodium karbonat dan $1 \mathrm{~mL}$ folin pada $2 \mathrm{~mL}$ supertanan, campur merata. Campuran diukur absorbansinya pada 660 $\mathrm{nm}$. Satu unit aktivitas protease didefinisikan sebagai sejumlah enzim yang melepaskan $1 \mu \mathrm{mol}$ tirosin per menit pada kondisi pengujian.

\section{Ekstraksi peptida tempe}

Ekstraksi peptida mengacu pada Gibs (1999) dan Rusdah (2016), sebanyak $1 \mathrm{~g}$ sampel tempe yang sudah dikering bekukan dicampur dengan $30 \mathrm{~mL}$ akuabides. Campuran diblender selama 3 menit, kemudian diinkubasi dalam waterbath suhu $30^{\circ} \mathrm{C}$ kecepatan $60 \mathrm{rpm}$ selama 60 menit. Larutan disentrifugasi pada kecepatan $20.000 \mathrm{~g}$ selama 15 menit. Supernatan 


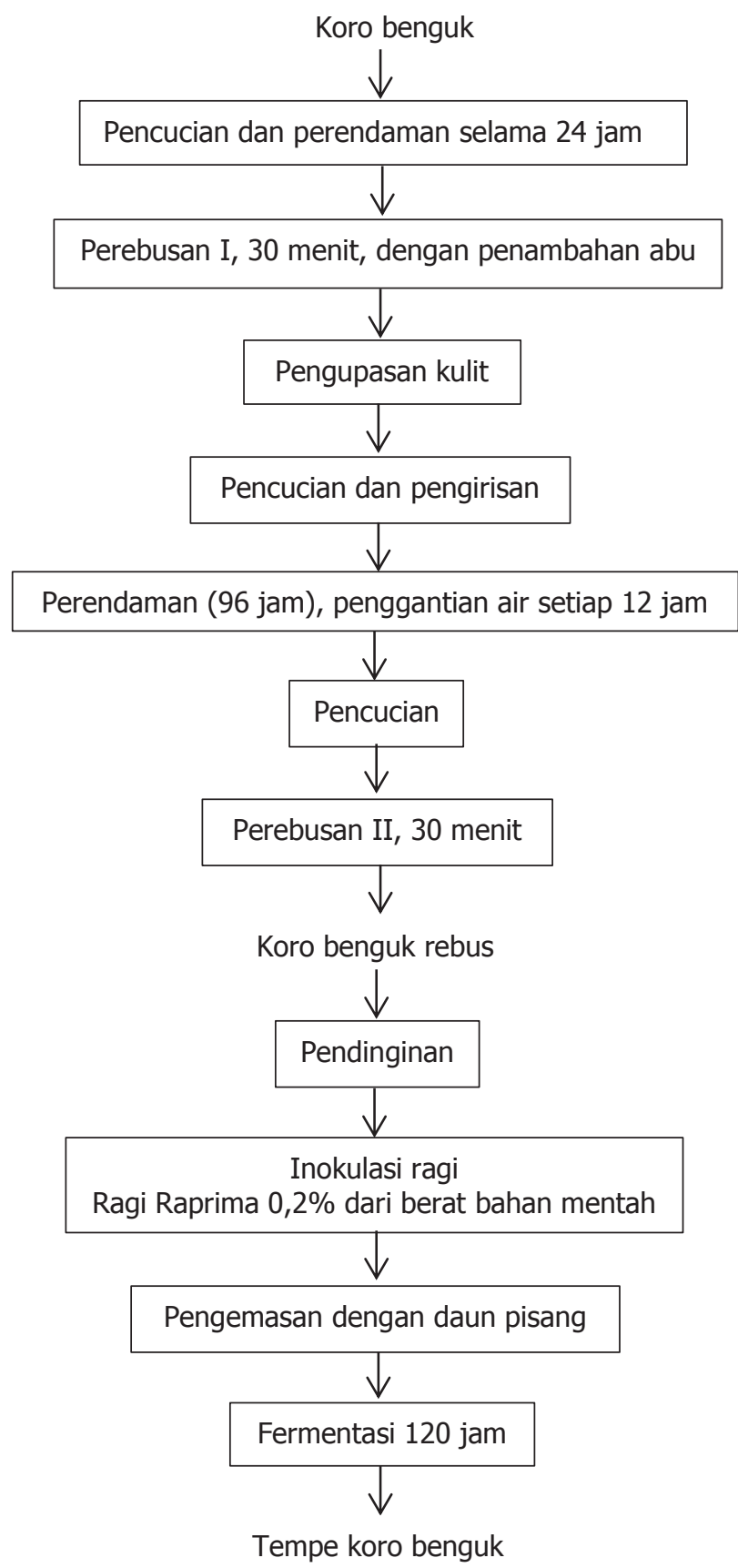

Gambar 1. Diagram alir pembuatan tempe koro benguk

merupakan ekstrak peptida.

\section{Analisa konsentrasi peptida dan derajat hidrolisis}

Pengukuran konsentrasi peptida dilakukan mengikuti Church dkk. (1983). Sodium tetra borat (Borat, $25 \mathrm{~mL} 100 \mathrm{mM}), 2,5 \mathrm{~mL} \mathrm{20 \%}(\mathrm{g} / \mathrm{g})$ sodium dodecyl sulfat (SDS) dan 1,1 mL OPA (40 mg OPA dilarutkan dalam $1 \mathrm{~mL}$ methanol dan $100 \mathrm{~mL} \beta$-mercaptoethanol) dicampur dengan $21,4 \mathrm{~mL} \mathrm{H}_{2} \mathrm{O}$. Ekstrak peptida tempe $(30 \mu \mathrm{L})$ ditambahkan secara langsung pada $1 \mathrm{~mL}$ reagen
OPA dalam cuvette $1,5 \mathrm{~mL}$. Larutan dicampurkan secara cepat dengan pembalikan dan diinkubasi pada suhu ruang selama 2 menit. Pembacaan absorbansi dilakukan pada $340 \mathrm{~nm}$. Penghitungan peptida diilakukan dengan kurva regresi linear dengan standar dipeptida Trypton. Perhitungan Degree of hydrolysis (DH) dengan metode OPA menggunakan Persaaman 1.

$$
\% D H=n \cdot 100 / N
$$

$\mathrm{n}$ adalah jumlah rata-rata ikatan peptide yang terhidrolisis dan $\mathrm{N}$ adalah jumlah total ikatan peptide per molekul protein (Spellman, 2003).

\section{Analisa pH}

Tingkat keasaman diukur dengan $\mathrm{pH}$ meter, $5 \mathrm{~g}$ sampel tempe diblender dalam $45 \mathrm{~mL}$ akuades hingga homogen kemudian diukur pHnya.

\section{Analisa Komposisi Asam Amino}

Komposisi asam amino penyusun protein koro benguk dianalisa menggunakan LC-MS/MS (the Waters Xevo TQD Triple Quadrupole). Sampel dihidrolisis menggunakan $\mathrm{HCl} \quad 6 \quad \mathrm{~N}$ kemudian dipanaskan menggunakan autoclave $110{ }^{\circ} \mathrm{C}$ selama 12 jam. Sampel dinetralisasi menggunakan $\mathrm{NaOH} 6 \mathrm{~N}$ dan difilter menggunakan siring filter $0,22 \mu \mathrm{m}$ dan diencerkan dengan akuabides dengan rasio 1:50 (v/v). Sebanyak 2 $\mu \mathrm{L}$ sampel diinjeksikan ke alat. Solven yang digunakan adalah: solvent A: $0,1 \%$ asam pentadecafluoroactanoat 99,5\%: 0,5 \% air/ $\mathrm{CH}_{3} \mathrm{CN}$ dengan $0,1 \%$ asam format. Solvent B terdiri dari $0,1 \%$ asam pentadecafluorooctanoat $10 \%$ : $90 \%$ air $/ \mathrm{CH}_{3} \mathrm{CN}$ dengan $0,1 \%$ asam format. Sampel dielusi pada suhu $50^{\circ} \mathrm{C}$ dan dengan kecepatan aliran $0,6 \mathrm{~mL} / \mathrm{menit}$.

\section{Analisa Proksimat (AOAC, 2005)}

Analisa proksimat dilakukan melalui beberapa tahapan, meliputi preparasi sampel, penentuan kadar air, penentuan kadar abu, penentuan kadar lemak, penentuan kadar protein, dan penentuan kadar karbohidrat by difference.

\section{Analisa Pola Protein}

Penentuan pola protein dilakukan menggunakan SDS PAGE yang didasarkan pada metode Laemli (1970). SDS-PAGE menggunakan resolving gel $13 \%$ dan stacking gel $5 \%$. Ekstrak peptida diencerkan menggunakan buffer sampel pada rasio 1:2. Bufer sampel terdiri dari Tris $\mathrm{HCl} 0,5 \mathrm{M} \mathrm{pH} \mathrm{6,8;} \mathrm{gliserol;} \mathrm{SDS} 10 \%(\mathrm{w} / \mathrm{v})$; $0,5 \%$ bromphenol blue $(\mathrm{w} / \mathrm{v})$ dan akuabides. Sampel 
dipanaskan pada suhu $100^{\circ} \mathrm{C}$ selama 4 menit. Sebanyak $20 \mu \mathrm{L}$ sampel dan $5 \mu \mathrm{L}$ marker protein diinjeksikan ke dalam sumuran. Gel kemudian dialiri arus listrik 220 volt selama kurang lebih 60 menit. Gel kemudian direndam dalam akuades selama 30 menit lalu diwarnai menggunakan commasie brilliant blue (CBB) dengan digoyang selama $1 \mathrm{jam}$. Setelah itu dilakukan destaining untuk menghilangkan CBB yang tidak terikat protein.

\section{HASIL DAN PEMBAHASAN}

\section{Komposisi Kimiawi Biji Koro Benguk}

Hasil analisa proksimat biji koro benguk dapat dilihat pada Tabel 1. Hasil tersebut menunjukkan bahwa kadar protein biji sebesar $26,75 \pm 0,06 \%$, sedikit lebih rendah dari hasil yang dilaporkan oleh Handajani (2001) (28,4-31\%) maupun Agbede dan Aletor (2005) $(27,5 \%)$. Kandungan protein pada sampel koro benguk yang digunakan pada penelitian ini sedikit lebih rendah dibanding dengan penelitian Kalidas (2014), yaitu sebesar 28,82\% pada koro benguk varietas biji putih.

Perbedaan kuantitas dan kualitas protein pada koro benguk dipengaruhi oleh variasi lokasi geografis (Sridhar dan Seena, 2006). Menurut Siddhuraju dkk. (1996) protein biji koro benguk didominasi oleh protein globulin dan albumin dengan total 22,7 g/100 g tepung biji. Protein menjadi komponen penting dalam fermentasi tempe karena protein inilah yang akan dihidrolisis oleh jamur tempe menjadi peptida-peptida yang berpotensi memiliki sifat bioaktif.

\section{Komposisi Asam Amino Koro Benguk}

Komposisi dan kuantitas asam amino suatu bahan pangan menjadi salah satu tolok ukur mutu bahan pangan itu sendiri. Komposisi asam amino biji koro benguk ditampilkan pada Tabel 2. Pada tabel tersebut terlihat bahwa total asam amino hidrofilik lebih banyak dibanding asam amino hidrofobik (mencapai hampir 2 kalinya). Dari asam amino hidrofilik, asam glutamate tertinggi jumlahnya, kemudian diikuti lisin, asam aspartate, dan arginine. Sementara itu untuk asam

Tabel 1. Komposisi proksimat biji koro benguk

\begin{tabular}{ll}
\hline Komponen & Koro benguk (\%) \\
\hline Lemak & $2,69 \pm 0,06$ \\
Protein & $26,75 \pm 1,29$ \\
Kadar Air & $15,3 \pm 0,01$ \\
Kadar Abu & $3,02 \pm 0,01$ \\
Karbohidrat (by diff) & $52,23 \pm 1,26$ \\
\hline
\end{tabular}

amino hidrofobik didominasi oleh asam amino leusin dan glisin, serta beberapa asam amino hidrofobik yang lain seperti isoleusin, valin, fenilalanin, dan prolin. Hasil ini sedikit berbeda dari penelitian yang disampaikan Sidduraju dkk. (1996) bahwa asam amino esensial yang terdapat pada biji koro benguk adalah valin, isoleusin, tirosin, dan fenilalanin. Keberadaan asam amino hidrofobik ini penting karena akan menentukan seberapa banyak peptide bioaktif yang terbentuk. Dari data komposisi asam amino hidrofobik biji koro benguk tersebut, dimungkinkan koro benguk dapat menghasilkan peptida bioaktif selama proses fermentasi menjadi tempe. Peptida bioaktif merupakan fragmen protein spesifik yang memiliki pengaruh positif pada tubuh (Kitts dan Weiler, 2003) dan pada umumnya memiliki berat molekul rendah (tersusun dari 2-20 asam amino), dan asam amino penyusunnya spesifik serta bersifat hidrofobik (Himaya dan Kim, 2012).

\section{Pertumbuhan Jamur Selama Fermentasi Tempe}

Pertumbuhan jamur dari ragi Raprima pada media biji koro benguk cukup lambat dibandingkan dengan biji kedele. Miselia jamur baru mulai muncul setelah 24 jam inkubasi, terlihat seperti serat kapas halus di beberapa permukaan biji koro benguk (Gambar 2a). Pada fermentasi 48 jam baru tercium aroma khas tempe dengan miselia jamur yang tumbuh menutupi seluruh permukaan biji koro benguk, sehingga tempe berwarna putih dengan tekstur yang kompak (Gambar 2b). Miselia-miselia putih yang menyelubungi biji koro benguk ini yang membuat tekstur tempe menjadi kompak (Sparringa dkk, 2002). Pada inkubasi 72 jam, tekstur menjadi sangat kompak dan mulai diproduksi spora hitam (Gambar 2c) yang menunjukkan bahwa kondisi pertumbuhan jamur sudah mulai menurun. Inkubasi 96 jam mulai terjadi fermentasi lanjut dengan bau amonia dan pada inkubasi 120 jam sudah terjadi pembusukan dengan ciri-ciri bau amonia yang tajam, tekstur lembek serta warna menjadi coklat (Gambar 2d). Pola pertumbuhan miselia jamur ini berhubungan dengan besarnya aktivitas protease yang diproduksi oleh jamur tempe tersebut (Elegado dan Fujio, 1993). Muzdalifah dkk. (2017) melaporkan bahwa perubahan warna pada fermentasi lanjut diakibatkan oleh perubahan biokimia selama fermentasi yaitu: 1) meningkatnya jumlah Rhizopus oligosporus yang memasuki fase kematian (death phase) dan adanya aktivitas mikroorganisme pembusuk; 2) kerusakan oksidatif asam lemak tidak jenuh (asam linoleat dan asam linolenat) hasil pemecahan lipid; 3) keberadaan vitamin B12 yang mengandung cobalt (berwarna merah). 
Tabel 2. Komposisi asam amino biji koro benguk

\begin{tabular}{lll}
\hline \multicolumn{2}{l}{ Komposisi asam amino } & $\mathrm{g} / 100 \mathrm{~g}$ protein \\
\hline \multicolumn{2}{l}{ Asam amino hidrofobik } & \\
2 & Alanin & $2,83 \pm 0,13$ \\
3 & Glisin & $4,19 \pm 0,01$ \\
4 & Valin & $3,86 \pm 0,07$ \\
5 & Isoleusin & $5,00 \pm 0,02$ \\
6 & Prolin & $3,91 \pm 0,03$ \\
7 & Fenilalanin & $3,50 \pm 0,10$ \\
8 & Metionin & $3,67 \pm 0,02$ \\
9 & Sistein & $0,27 \pm 0,01$ \\
& Total asam amino hidrofobik & $0,17 \pm 0,06$ \\
Asam amino hidrofilik & $27,44 \pm 0,05$ \\
1 & Asam aspartat & \\
2 & Asam glutamat & $8,63 \pm 0,22$ \\
3 & Arginin & $11,32 \pm 0,11$ \\
4 & Lisin & $7,62 \pm 0,18$ \\
5 & Histidin & $8,80 \pm 0,08$ \\
6 & Serin & $3,09 \pm 0,32$ \\
7 & Treonin & $3,52 \pm 0,09$ \\
8 & Tirosin & $4,07 \pm 0,16$ \\
& Total asam amino hidrofilik & $1,16 \pm 0,04$ \\
\hline & & $48,25 \pm 0,15$ \\
\hline
\end{tabular}
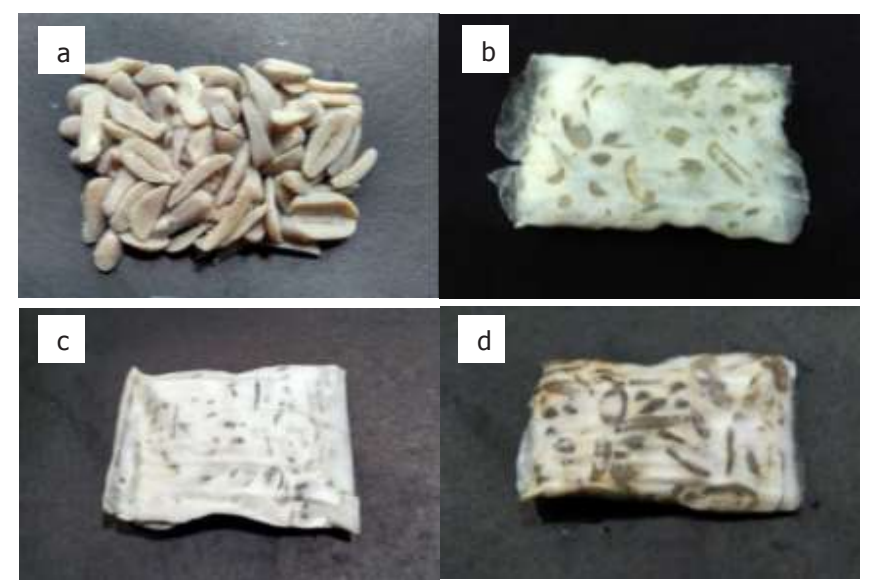

Gambar 2. Pertumbuhan jamur selama fermentasi tempe koro benguk dengan ragi Raprima. a) inkubasi 24 jam; b) inkubasi 48 jam; c) inkubasi 72 jam; d) inkubasi 120 jam

\section{Perubahan pH Selama Fermentasi Tempe}

$\mathrm{pH}$ tempe koro benguk pada 0 jam fermentasi sekitar 6,9-7,02. Kemudian turun selama fermentasi

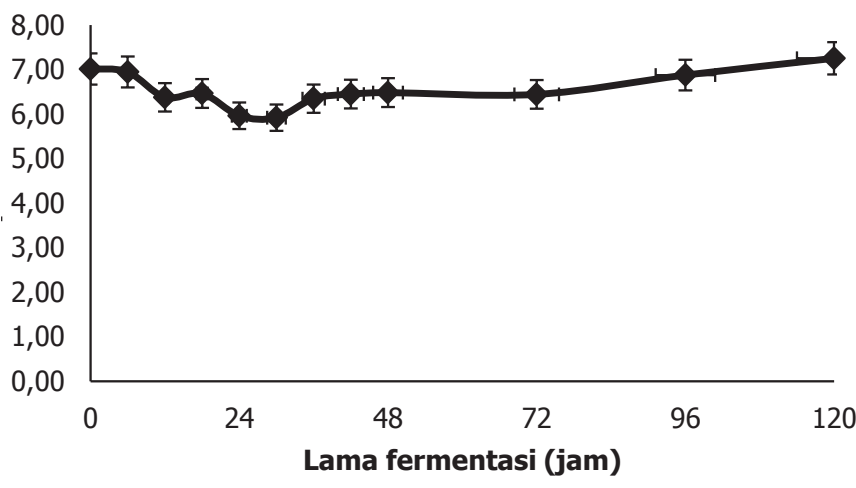

Gambar 3. Perubahan pH selama fermentasi tempe koro benguk yang diinokulasi dengan ragi Raprima

dan pada jam ke-30 $\mathrm{pH}$ menjadi 5,92 ( $\mathrm{pH}$ terendah) (Gambar 3). Penurunan pH ini dikarenakan tumbuhnya bakteri asam laktat bersama dengan Rhizopus oligosporus selama fermentasi tempe. Bakteri asam laktat akan menghasilkan asam laktat yang berpengaruh pada penurunan $\mathrm{pH}$ tempe dan sekaligus berfungsi menghambat pertumbuhan mikroorganisme pembusuk (Feng, 2005). Inkubasi lebih lanjut akan menyebabkan kenaikan $\mathrm{pH}$ tempe kembali sampai akhir fermentasi ( $\mathrm{pH} 7,25)$ (Gambar 3). Hasil ini berbeda dengan yang dilaporkan oleh Egountly dan Aworth (2003) pada fermentasi koro benguk dengan Rhizopus oligosporus, kenaikan $\mathrm{pH}$ dari 5,10 menjadi 5,98 terjadi selama fermentasi 48 jam. Tetapi hasil ini sesuai dengan laporan studi oleh Muzdalifah dkk. (2017) yang menyatakan bahwa pada fermentasi tempe kedelai dengan Rhizopus oligosporus hingga 160 jam (extended fermentation) terjadi kenaikan $\mathrm{pH}$ dari 5,0 menjadi 7,5. Peningkatan $\mathrm{pH}$ terjadi karena aktivitas protease yang dihasilkan selama fermentasi tempe sehingga menyebabkan degradasi protein biji koro benguk. Aktivitas protease makin meningkat maka proses degradasi protein makin besar sehingga pH naik (Steinkraus, 1995). Produk hasil degradasi protein dapat berupa peptida, asam amino dan substansi dekomposisi lainnya seperti amonia (Sing dkk., 2014). Senyawa amonia ini yang menyebabkan pH naik.

\section{Aktivitas Protease, Kadar Peptide, dan Derajat Hidrolisis}

Pada Gambar 4a menunjukkan bahwa aktivitas protease mulai terdeteksi setelah 24 jam fermentasi, pada saat itu miselia mulai tumbuh di permukaan biji koro benguk (Gambar 2a). Aktivitas protease terus mengalami peningkatan sampai dengan fermentasi jam ke-96 (aktivitas tertinggi, yaitu sebesar 17,15 $\pm 3,28$ ) dan kemudian menurun pada fermentasi jam ke-120. 


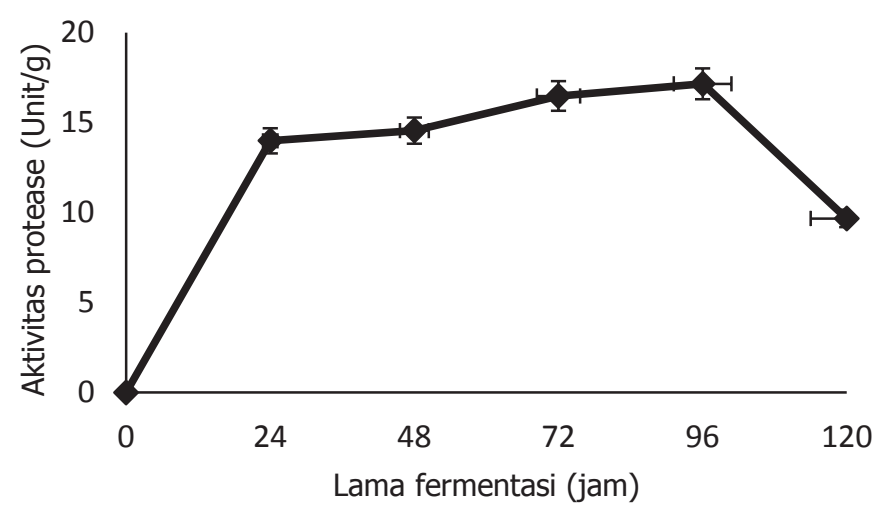

(a)

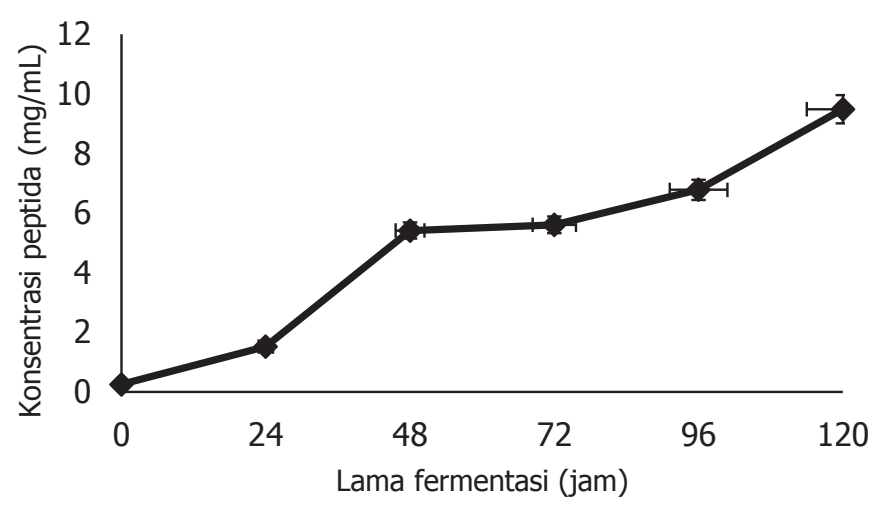

(b)

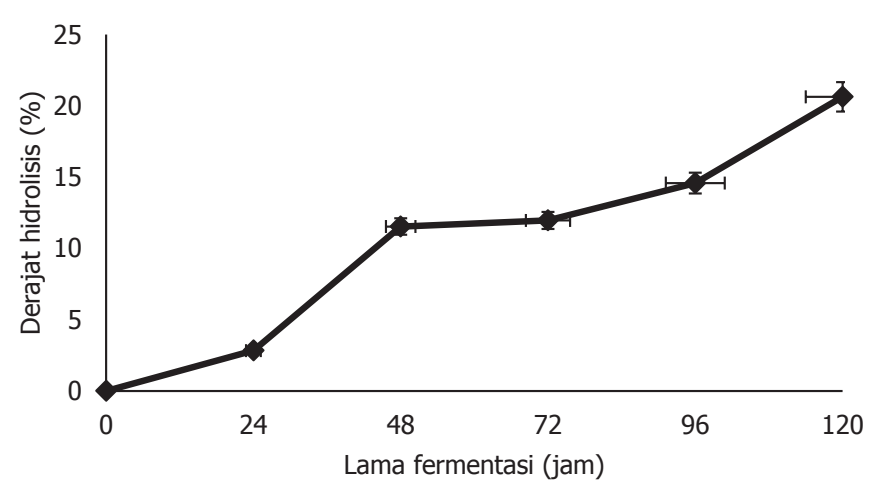

(c)

Gambar 4. Aktivitas protease (a), kadar peptida (b), dan derajat hidrolisis protein (c) selama fermentasi tempe koro benguk yang diinokulasi dengan ragi Raprima

Ditinjau dari aktivitas proteasenya, produksi enzim ini lebih lambat (tempe kedelai yang diinokulasi dengan Rhizopus oligosporus aktivitas protease meningkat tajam pada jam 12-24 fermentasi) (Karmini dkk., 1996). Hal tersebut disebabkan oleh biji koro benguk lebih keras dibandingkan biji kedelai. Aktivitas protease yang lambat tersebut menyebabkan proses fermentasi untuk menjadi tempe juga lambat (72 jam) (Gambar 2).

Hidrolisis protein biji koro benguk oleh protease akan menghasilkan protein dengan berat molekul pendek dan peptida. Seiring meningkatnya aktivitas protease selama fermentasi tempe, kadar peptida juga mengalami peningkatan sampai fermentasi jam ke 120 (Gambar 4b). Hal ini bisa dilihat pada Gambar 2d bahwa tempe yang difermentasi selama 120 jam, teksturnya lembek dan berbau amonia (pada fermentasi 96 jam tekstur belum begitu lunak). Derajat hidrolisis (DH) mengalami kenaikan tajam pada 24 jam pertama fermentasi (Gambar 4c). Inkubasi yang lebih lama walaupun sedikit menaikkan DH tetapi tidak setajam di awal fermentasi, kemudian setelah 48 jam fermentasi, prosentase protein terhidrolisis relative stabil (sekitar 45\%).

Angka ini sebanding dengan persen hidrolisis tempe biji-bijian lain, seperti misalnya tempe kedelai dengan inokulum Rhizopus oligosporus dan Bacillus substilis memiliki nilai DH sebesar $20 \%$ setelah 48 jam fermentasi (Weng dan Chen, 2011), dan meningkat hingga $46 \%$ jika difermentasi menggunakan rotating drum drier ( $R D R$ ) walaupun oleh de-Reu dan koleganya keterangan tersebut disanggah (tidak ada perbedaan $\mathrm{DH}$ antara fermentasi secara tradisional maupun RDR) (de Reu dkk., 1995). DH pada fermentasi tempe bergantung dari strain jamur (Baumann dan Bisping, 1995) dan kondisi proses (Ikasari dan Mitchell, 1998). DH juga berhubungan dengan aktivitas protease selama fermentasi yaitu makin tinggi aktivitas protease maka makin banyak peptida yang dihasilkan sehingga berakibat pada $\mathrm{DH}$ yang makin tinggi (StarzyńskaJaniszewska dkk., 2015)and the effect of inoculum composition on the protein level and in vitro protein bioavailability in products. Material and methods. Fermentation substrate were soaked and cooked grass pea seeds. Material was mixed with single- or mixedculture inoculum, and incubated in perforated plastic bags at $30^{\circ} \mathrm{C}$ for $32 \mathrm{hrs}$. In the products, the proteolytic activity (pH 3, 5 and 7.

\section{Pola Protein Selama Fermentasi Tempe}

Pola perubahan protein selama fermentasi tempe koro benguk ditunjukkan pada Gambar 5. Dari hasil SDS PAGE protein koro benguk terlihat mulai munculnya pita-pita protein baru setelah 12 jam fermentasi yaitu protein dengan berat molekul (BM) sekitar $83 \mathrm{kDa}$. Pada jam ke 48 selain muncul beberapa pita protein dengan BM rendah (77 kDa, $63 \mathrm{kDa}, 46 \mathrm{kDa}, 24$ $\mathrm{kDa}$ ) juga muncul pita dengan BM tinggi yang pada awalnya (fermentasi 0 jam) tidak ditemukan (195 kDa 


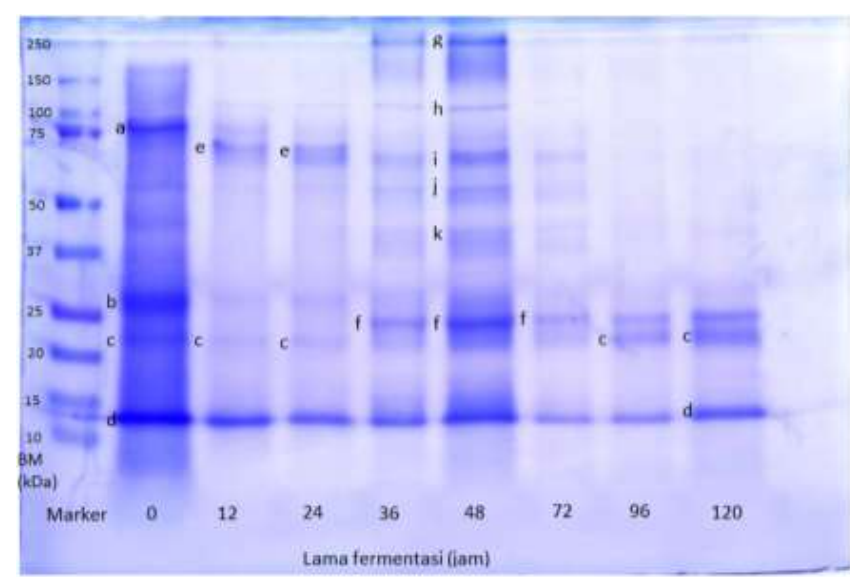

Gambar 5. Pola protein pada fermentasi tempe koro benguk menggunakan inokulum Raprima

Keterangan: a. 100 kDa, b. 27 kDa, c. 21 kDa, d. 11 kDa, e. 83 kDa, f. 24 kDa, g. 195 kDa, h. 115 kDa, i. 77 kDa, j. 63 kDa, k. $46 \mathrm{kDa}$

dan $115 \mathrm{kDa}$ ). Hal ini dimungkinkan karena terjadinya hidrolisa protein biji koro benguk yang mempunyai BM sangat besar selama proses fermentasi sehingga yang awalnya protein tersebut tidak larut (mengendap pada preparasi ekstrak) dengan hdrolisis menjadikannya larut dan muncul sebagai pita dengan BM tinggi. Pada akhir fermentasi (jam ke-120) terdapat 3 pita protein $\mathrm{BM}$ rendah yang mendominasi, yaitu yang mempunyai BM $24 \mathrm{kDa}, 21 \mathrm{kDa}$, dan $11 \mathrm{kDa}$. Pita dengan BM 11 kDa selalu ditemukan pada tiap jam fermentasi. Hal ini menunjukkan protease yang dihasilkan oleh jamur dalam ragi Raprima dapat menghidrolisis protein biji koro benguk menjadi protein dengan berat molekul kurang dari $25 \mathrm{kDa}$ sehingga berpotensi memiliki sifat bioaktif.

\section{KESIMPULAN}

Biji koro benguk berpotensi mengasilkan protein yang bersifat bioaktif, ditinjau dari kandungan asam amino hidrofobiknya. Proses fermentasi menjadi tempe terbukti dapat menghasilkan fragment protein atau peptide dengan BM yang cukup rendah, kurang dari $25 \mathrm{kDa}$. Hasil ini sejalan dengan kenaikan nilai derajat hidrolisis dan kadar peptida, yaitu makin lama proses fermentasi berlangsung makin tinggi nilainya. Aktivitas bioaktif dari protein/peptida hasil fermentasi tempe koro benguk ini sedang dikaji lebih lanjut.

\section{UCAPAN TERIMA KASIH}

Penelitian ini dibiayai oleh Direktorat Riset dan
Pengabdian Masyarakat, Direktorat Jenderal Penguatan Riset dan Pengembangan, Kementerian Riset, Teknologi dan Pendidikan Tinggi, Tahun Anggaran 2018 melalui skema Penelitian Tim Pascasarjana (No. Kontrak 1778/ UN1/DITLIT/DIT-LIT/LT/2018). Untuk itu peneliti mengucapkan terima kasih yang sebesar-besarnya.

\section{KONFLIK KEPENTINGAN}

Penulis menyatakan bahwa data dalam paper ini asli dan belum pernah dipublikasikan, serta tidak ada konflik kepentingan.

\section{DAFTAR PUSTAKA}

Agbede, J.O., dan V.A. Aletor. (2005). Studies of the Chemical Composition and protein Quality Evaluataion of Differently Processed Canavalia ensiformis and Mucuna pruriens Seed Flours. Journal of Food Composition and Analysis. 18, 89-103. DOI: 10.1016/j.jfca.2003.10.011

Baumann, U., dan B. Bisping. (1995). Proteolysis during tempe fermentation. Food Microbiology 12:39-47. DOI: 10.1016/S0740-0020(95)80077-8

Church, F.C., H.E. Swaisgood, D, H, Porter, dan G.L. Catignani. (1983). Spectrophotometric assay using o phthaldialdehyde for determination of proteolysis in milk and isolated milk proteins. J. Dairy Sci. 66, 1219- 1227. DOI: $10.3168 /$ jds.S0022-0302(83)81926-2

de Reu, J.C., R.M. ten Wolde, J. de Groot, M. J. R. Nout, F. M. Rombouts, dan H. Gruppen. (1995). Protein Hydrolysis during Soybean Tempe Fermentation with Rhizopus oligosporus. Journal of Agricultural and Food Chemistry, 43(8), 2235-2239. DOI:10.1021/jf00056a050

Egountly, M. dan O.C. Aworh. (2003). Effect of soaking, dehulling, cooking, and fermentation with Rhizopus oligosporus on the oligosaccharides, Trypsin inhibitor, Phytic acid, and Tannins of Soybean (Glycine max Merr.), Cowpea (Vigna unguiculata L. Walp.) and Groundbean (Macrotyloma geocarpa Harms). Journal of Food Engineering 56, 249-254. DOI: 10.1016/S02608774(02)00262-5

Elegado, B. F. dan Y. Fujio. (1993). Growth of Rhizopus strains on soybean and their protease formation. J. Fat. Agr. 37 (34), 315-324. https://catalog.lib.kyushu-u. ac.jp/opac_download_md/24024/p315.pdf

Feng, X. M., A. R. Eriksson, dan J. Schnürer. (2005). Growth of lactic acid bacteria and Rhizopus oligosporus during barley tempeh fermentation. International Journal of Food Microbiology, 104(3), 249-256. DOI: 10.1016/j. ijfoodmicro.2005.03.005

Gibbs, B. F. (1999). Production and Characterization of Bioactive Peptides from Soy Fermented Foods and Their Hydrolysates. Dissertation. Department of Food Science 
and Agricultural Chemistry, MacDonald Campus, Mcgili University. Canada. DOI: 10.1.1.427.5960

Gibbs, B.F., A. Zougman, R. Masse, dan C. Mulligan. 2004. Production and characterization of bioactive peptides from soy hydrolysate and soy-fermented food. Food Research International 37(2), 123-131. DOI: 10.1016/j. foodres.2003.09.010

Handajani, S. (2001). Indigenous mucuna tempe as functional food. Asia Pacific. J. Clin. Nutr (2001).10(3), 222-225. DOI: $10.1046 / j .1440-6047.2001 .00243 . x$

Hidayat, Nur, M.C. Padaga dan S. Suhartini. (2006). Mikrobiologi Industri. Andi. Yogyakarta

Himaya, S. dan R. B. Kim. (2012). An active peptida purified from gastrointestinalenzyme hidrolisate of Pasific cod skin gelatin attenuates angiotensin I converting enzyme activity and cellular oxidative stress. Food Chem 132, 1872-1882. DOI: 10.1016/j.foodchem.2011.12.020

Ikasari, L., dan D.A. Mitchell. (1998). Mimicking gas and temperature changes during enzyme production by Rhizopus oligosporus in solid-state fermentation. Biotechnology letters, Vol. 20, N0. 4. pp. 349-353. DOI: 10.1023/A:1005319128217

Kalidass, C., dan A. K. Mahapatra. (2014). Evaluation of the proximate and phytochemical compositions of an underexploited legume Mucuna pruriens var. utilis (Wall ex Wight) LH Bailey. International Food Research Journal, 21(1), 303-308. http://agris.upm.edu.my:8080/ dspace/handle/0/10928

Karmini, M., D. Sutopo, dan Hermana. (1996). Aktivitas enzim hidrolik kapang Rhizopus sp pada proses fermentasi tempe. Penelitian Gizi dan Makanan 19, 93-102. http:// ejournal.litbang.depkes.go.id/index.php/pgm/article/ view/2302/2392

Kitts, D. dan K. Weiler. (2003). Bioactive Proteins and Peptidas from Food Sources. Applications of Bioprocesses used in Isolation and Recovery. Curr Pharm. Design. 9, 13091323. DOI: $10.2174 / 1381612033454883$

Muzdalifah, D., Z. A. Athaillah, W. Nugrahani, dan A. F. Devi. (2017). Colour and $\mathrm{pH}$ changes of tempe during extended fermentation. In AIP conference Proceedings. AIP Publishing. Vol. 1803, No. 1, p. 020036. DOI: $10.1063 / 1.4973163$
Rusdah. (2016). Antioxidative Peptides of Tempe from Indonesia. Thesis. Graduate School Bogor Agricultural University. Bogor. http://repository.ipb.ac.id/ handle/123456789/81450

Siddhuraju, P., K. Vijayakumara, dan K. Janardhanan. (1996). Chemical composition and protein quality of little knownlegume, velvet bean (Mucuna pruriens (L). DC). J. Agric. Food Chem. 44, 2636-2641. DOI: 10.1021/ jf950776x

Singh, B.P., S. Vij, dan S. Hati, (2014). Functional significance of bioactive peptides derived from soybean. Peptides, 54, 171-179. DOI: 10.1016/j.peptides.2014.01.022

Sparringa R.A., M. Kendall, A. Westby, dan J.D. Owens. (2002). Effects of temperature, $\mathrm{pH}$, water activity and $\mathrm{CO} 2$ concentration on growth of Rhizopus oligosporus NRRL 2710. Journal of Applied Microbiology. 92 (2), 329-337. DOI: $10.1046 /$ j.1365-2672.2002.01534.x

Spellman, D., E. Mc Evoy, G. O'Cuinn, dan R.J. FitzGerald. (2003). Proteinase and exopeptidase hydrolysis of whey protein: Comparison of the TNBS, OPA, and $\mathrm{pH}$ stat methods for quantification of degree of hydrolysis. International Dairy Journal 13, 447-453. DOI: 10.1016/ S0958-6946(03)00053-0

Sridhar, K.R, dan S. Seena. (2006). Nutritional and antinutritional significance of four unconventional legumes of the genus Canavalia - a comparative study. Food Chemistry 99, 267-288. DOI: 10.1016/j.foodchem.2005.07.049

Steinkraus, K.H. (1995). Handbook of Indigenous Fermented Foods, 2 revised and expanded edn. Marcel Dekker. New York.

Starzyńska-Janiszewska, A., B. Stodolak, dan A. Wikiera, (2015). Proteolysis in tempeh-type products obtained with Rhizopus and Aspergillus strains from grass pea (Lathyrus Sativus) seeds. Acta Sci. Pol. Technol. Aliment., 14, 125-132. DOI: 10.17306/J.AFS.2015.2.14

Weng, T. M. dan M. T. Chen. (2011). Effect of two step fermentation by Rhizopus oligosporus and Bacillus substilis on protein of fermented soybean. Food Science Technology. Res. 17 (5), 393-400. DOI: $10.3136 /$ fstr.17.393 